\title{
Review on the Social, Collective and National Identity Areas of Third Generation Turkish Young Adults Living in Germany
}

\author{
Adnan Kulaksızoğlu ${ }^{1 *}$, Besra Taş ${ }^{2}$ \\ ${ }^{1}$ Biruni Üniversitesi, Faculty of Education, Psychological Counseling and Guidance Department, Istanbul/Turkey (ORCID: 0000-0001-9620-0856) \\ 2 İstanbul Sabahattin Zaim Üniversitesi, Faculty of Education, Psychological Counseling and Guidance Department, Istanbul/Turkey (ORCID: 0000-0002-1273-4429)
}

(First received 26 August 2018 and in final form 4 March 2019)

(DOI: 10.31590/ejosat.535156)

ATIF/REFERENCE: Kulaksizoglu, A. \& Tas, B. (2019). Review on the Social, Collective and National Identity Areas of Third Generation Turkish Young Adults Living in Germany. European Journal of Science and Technology, (15), 237-251.

\begin{abstract}
It is stated that the largest portion of immigrant origin living in Germany consists of people of Turkish origin. It is mentioned that Germany has a population of 82.4 million in 2016. Of these, 18.6 million are of immigrant origin. Migrants from Turkey are 2.8 million. These constitute 3.4 percent of the general population. Turkish people living in Germany, while maintaining their religious, national and ethnic identities on the one hand, form collective identities on the other. Immigrants who want to adapt to Germany among the Turkish people living in Germany aim to develop a collective identity in order to adapt more easily. Turkish people who live in Germany or come to Turkey as workers shows much difference in terms of culture, value and religion compared to the individuals who live in Turkey. This is because they are immigrants. As a result of the study, it is seen that there is a significant difference between the gender variable and the scale total score and the collective sub-dimension. Nevertheless, when the question "What are the problems of citizens of Turkish origin living in Germany?" is asked, the answers related exclusion, discrimination and cultural differences are collected. When the most suitable nationality is asked to the participants, all participants answered as "I am Turkish." Nonetheless, it is seen that the participants with German citizenship, Turkish citizenship and Turkish and German citizenship are involved. Therefore, it is possible to suggest that the participants' citizenship status has not changed their answer regarding the most suitable nationality.
\end{abstract}

Keywords: National Identity, Third Generation, Turkish Young Adults, Germany.

\footnotetext{
* Corresponding Author: Biruni University, Faculty of Education, Psychological Counseling and Guidance Department, Istanbul/Turkey, ORCID: 0000-0001-9620-0856, akulaksizoglu@biruni.edu.tr
} 


\section{Introduction}

Turkish people started to come to Germany as workers in 1960s. Since then, the Turkish population in Germany has been in a continuous increase. In 2002, Germany had a population of 82 million, and the population of Turkish people there had reached 2.5 million, including 500,000 Turkish, who were German citizens until 2002. 32\% of Turks in Germany are under 18 years old and $71 \%$ are under 35 years old. Most Turkish youth living in Germany in 2000s are born in Germany (Goldenberg, 2000:9).

It is stated that Germany's population will be 82.4 million in 2016. Of these, 18.6 million are of immigrant origin. 9.6 million of immigrant individuals have German citizenship. The oldest of the foreigners of immigrant origin are of Turkish descent. Migrants from Turkey are 2.8 million. These constitute 3.4 percent of the general population.

In the second place, there are 1.9 million immigrants from Poland. The reasons why the Polish people come to Germany are different. It is stated that these reasons are mostly asylum, defection, family, education and work. (Schu, 2017).

Whether they are German citizens or not, Turkish people living in Germany have difficulty because they do not know the language of the country they live in sufficiently or they are unemployed, they have economic troubles or they cannot adapt to the German society for one reason or another. Another reason why individuals, especially young people, have problems is their parents' attitudes towards them. In traditional Turkish society, strong parent-child relationships are very common in the family. In the study regarding the relationships between the attitude and problems of parents, Kulaksizoğlu (2002/2003) revealed that $71 \%$ of third generation Turkish young adults state that they miss their relatives in Turkey even though $83 \%$ of them were born in Germany. This shows that the family ties and kinship relations of Turkish society are strong.

$43.3 \%$ of participants stated that they are afraid of sexual diseases. Germany, which experienced a more open and comfortable relationship of girls and boys than Turkey, is a country of young people begin sexual activity at an early age. The increasing prevalence of sexually transmitted diseases and the lack of treatment of certain diseases frighten young people who have active sexual life.

Öztunç, Bilge and Bilge (2015) found that there is a difference in gender and income level variables in terms of personality disorders in their study on whether there is a difference between the interaction of gender, income level and personality disorders.

In some Turkish families in Germany, parents may show excessive protection or pressure and control over the child. Researches that study parent-child relationship between child rearing attitudes and children's responses have focused on two different parental attitudes: democratic attitude and authoritarian attitude.

Parents who demonstrate democratic attitudes towards children recognize and value them as separate individuals and encourage an independent personality development. Parents who behave in a democratic way respect the child as a person and pave the way for appropriate behavior according to the level of development. The child is granted equal rights within the family. The child's needs are met and unrequited love is shown. Parents who behave democratically use their reward and punishment in an intelligent way to control their children's behaviors and have healthy expectations about their behavior (Sprinhall ve Collins, 1884:218).

Parents who have authoritarian attitude set standards for their child's behavior. He believes that the words of parents should be accepted as truth. In authoritarian families, the parent is strict, rigorous and controlled. Children are taught to be respectful to authority (Sprinthall and Collins, 1984:217). Children who grow up with authoritarian attitudes are children who do not think flexibly and behave in an emotional way. This structure of thinking alienates the person to his/her environment and those who grow up with an authoritarian attitude are more likely to get along well with those who think like themselves (Daresh, 1978:479).

It is widespread that the Turkish population's personality disorders can be explained by demographic characteristics that people have.

It is a matter of curiosity as to how the attitudes of child-rearing are in Turkish families living in Germany, whether their attitudes change with their stay in Germany or with their parents' education.

\subsection{Identities of Turkish Immigrants Living in Germany}

Definition of immigrant in Germany include "Migranten" (Immigrant), "Zuwanderer" (A resident from a different area), "Person mit Zuwanderungsgeschichte" (A resident with history) and "'Person mit Migrationshintergrund" (A person with immigration history) in the federal departments. Individuals with a migrant background are defined as people who have an immigrant history and whose parent settles in Germany after 1949 and people who are raised or born in Germany (InterIkultur, 2011). Turkish people living in Germany, while maintaining their religious, national and ethnic identities on the one hand, form collective identities on the other. Immigrants who want to adapt to Germany among the Turkish people living in Germany aim to develop a collective identity in order to adapt more easily. The collective identity means to carry an individual's own identity and to develop an identity which belongs to the society he/she lives in. Turkish people who live in Germany or come to Turkey as workers shows much difference in terms of culture, value and religion compared to the individuals who live in Turkey. This is because they are immigrants. Sackmann, Schultz, Prümm, Peters (2005) state that immigrants are classified into their roots and nationalities, while explaining the collective identities of immigrants. This leads to the immigrants defining themselves and "self-reflection" occurs. However, collective identity is not only due to immigration process. What is decisive for the self-definition of immigrants is their self-positioning in the new society. Collective identity is the goal of immigrants to integrate themselves with the new society as well as to preserve their national roots. Furthermore, the formation of collective identity differs from ethnic, religious and national identity (Quoted by Akkaş, 2009/2010, p. 113f).

\subsection{Purpose of the Study}


This study aims to examine the personal, social, collective and national identity fields of third generation Turkish young adults living in Germany and mostly in the ages of 15-30.

\section{Method}

\subsection{Research Methodology}

This study aims to examine the personal, social, collective and national identity areas of Turkish people living in Germany. In this study, the screening model is based on quantitative research methods. Screening models are studies of a whole group of the universe or a group or sample taken from this universe in order to reach a general opinion about the universe in a phase consisting of a large number of elements (Karasar, 2015). The research has a quantitative methodology because numerical data is obtained as the result of the scale used in the research.

\subsection{Data Collection Tool}

In the study, Personal Information Sheet and an Individual Identity Scale are applied on the participants. 21 questions are asked on the personal information form. Personal information form questions are prepared by the authors.

Individual Identity Scale:

Identity Questionnaire, from which the scale questions applied are adapted and prepared by Cheek ve Tropp (1995), is translated to Turkish by Çoşkun (2004).

\subsection{Data Analysis}

When the scale data are analyzed, the SPSS 23.0 package program is used. According to the analysis results, tables are created. Comments are made using the data in the tables.

It is analyzed whether the data obtained in the study are normally distributed and it is seen that the data have normal distribution when the $\mathrm{p}$ value is greater than .05 . Variance analysis and correlations or T-tests are prepared and applied according to the level of variables with descriptive analysis.

\section{Findings}

Table 1. Participants' Demographic Data

\begin{tabular}{|c|c|c|c|}
\hline Group & Variable & $\mathrm{N}$ & $\mathrm{f}(\%)$ \\
\hline \multirow{2}{*}{ Gender } & Male & 106 & 63,9 \\
\hline & Female & 60 & 36,1 \\
\hline \multirow{3}{*}{ Marital Status } & Married & 49 & 29,5 \\
\hline & Single & 101 & 60,8 \\
\hline & Divorced & 16 & 9,6 \\
\hline \multirow{7}{*}{ Education Status } & Illiterate & 0 & 0 \\
\hline & Primary School & 0 & 0 \\
\hline & Middle School & 0 & 0 \\
\hline & High School & 4 & 2,4 \\
\hline & College & 50 & 30,1 \\
\hline & University & 61 & 36,7 \\
\hline & Master/Doctorate & 51 & 30,7 \\
\hline \multirow{2}{*}{ Receiving Education in Germany } & Yes & 93 & 56,0 \\
\hline & No & 73 & 44,0 \\
\hline \multirow{2}{*}{ Do you have a job? } & Yes & 84 & 50,6 \\
\hline & No & 82 & 49,4 \\
\hline \multirow{2}{*}{ Occupational Certificate Status } & Yes & 73 & 44,0 \\
\hline & No & 93 & 56,0 \\
\hline \multirow{2}{*}{$\begin{array}{l}\text { Vocational Learning Course/School } \\
\text { Completion }\end{array}$} & Yes & 94 & 56,6 \\
\hline & No & 72 & 43,4 \\
\hline \multirow{2}{*}{ Working Status } & Yes & 86 & 51,8 \\
\hline & No & 80 & 48,2 \\
\hline \multirow{2}{*}{ Citizenship } & I am a German citizen & 57 & 34,3 \\
\hline & I am a Turkish citizen & 58 & 34,9 \\
\hline
\end{tabular}




\begin{tabular}{|c|c|c|c|}
\hline & German and Turkish citizen & 51 & 30,7 \\
\hline \multirow{3}{*}{ Generation Living in Germany } & First Generation & 0 & 0 \\
\hline & Second Generation & 79 & 47,6 \\
\hline & Third Generation & 87 & 52,4 \\
\hline \multirow{4}{*}{ Knowledge of German } & Very Good & 51 & 30,7 \\
\hline & Good & 52 & 31,3 \\
\hline & Intermediate & 63 & 38,0 \\
\hline & Poor & 0 & 0 \\
\hline \multirow{4}{*}{ Knowledge of Turkish } & Very Good & 66 & 39,8 \\
\hline & Good & 53 & 31,9 \\
\hline & Intermediate & 47 & 28,3 \\
\hline & Poor & 0 & 0 \\
\hline \multirow{3}{*}{ Frequency of Visiting Turkey } & Every year & 78 & 47,0 \\
\hline & Every $2-3$ years & 86 & 51,8 \\
\hline & Every 4-5 years & 2 & 1,2 \\
\hline \multirow{3}{*}{$\begin{array}{l}\text { The Most Appropriate Expression to } \\
\text { You }\end{array}$} & I am Turkish & 166 & 100 \\
\hline & I am German of Turkish origin & 0 & 0 \\
\hline & I am German & 0 & 0 \\
\hline \multirow{6}{*}{ Father's Educational Status } & Illiterate & 29 & 17,5 \\
\hline & Primary School & 25 & 15,1 \\
\hline & Middle School & 22 & 13,3 \\
\hline & High School & 20 & 12,0 \\
\hline & College & 34 & 20,5 \\
\hline & University & 36 & 21,7 \\
\hline \multirow{6}{*}{ Mother's Educational Status } & Illiterate & 46 & 27,7 \\
\hline & Primary School & 37 & 22,3 \\
\hline & Middle School & 41 & 24,7 \\
\hline & High School & 42 & 25,3 \\
\hline & College & 0 & 0 \\
\hline & University & 0 & 0 \\
\hline \multirow{5}{*}{ Family Income Level } & Poor & 0 & 0 \\
\hline & Lower Middle Income & 2 & 1,2 \\
\hline & Middle Income & 82 & 49,4 \\
\hline & Upper Middle Income & 82 & 49,4 \\
\hline & Rich & 0 & 0 \\
\hline & TOTAL & 166 & 100 \\
\hline
\end{tabular}

When Table 1 is examined, the findings of individual personal data are listed as follows:

$\checkmark 63.9 \%$ (106) of the participants are male while $36.1 \%$ (60) are female.

$\checkmark 29,5 \%$ (49) of the participants are married, 60,8\% (101) are single and 9,6\% (16) are divorced.

$\checkmark$ When the participants' educational status is observed, it is seen that $2.4 \%$ (4) are high school graduates, $30.1 \%$ (50) are college graduates, $36.7 \%(61)$ are university graduates and $30.7 \%$ (51) are master/doctorate graduates.

$\checkmark 56 \%$ of the participants studied in Germany while the others did not.

$\checkmark 50.6 \%$ of the participants have a profession while the others do not have a profession.

$\checkmark 56 \%$ of the participants do not have an occupational certificate while the others have a certificate.

$\checkmark 56,6 \%$ of the participants have finished a course/school for vocational learning course/school while the others have not.

$\checkmark 51,8 \%$ of the participants work while the others do not.

$\checkmark$ It is seen that 34,3\% (57) of the participants are German citizens, 34,9\% (59) are Turkish citizens and 30,7\% (51) are both German and Turkish citizens.

$\checkmark$ The rate of participants who state that they are the second generation living in Germany is $47,6 \%$ (79) and the rate of those who say that they are the third generation is $52,4 \%$ (87).

$\checkmark 30.3 \%$ of the participants state that their German is very good, 31.3\% state that their German is good and 38\% state that their German is intermediate. 
$39,8 \%$ of the participants state that their Turkish is very good, $31,9 \%$ state that their Turkish is good and $28,3 \%$ state that their Turkish is intermediate.

$\checkmark 47 \%$ of the participants state that they go to Turkey every year, 51,8\% state that they go to Turkey every 2-3 years and $1,2 \%$ state that they go to Turkey every $3-5$ years.

$\checkmark$ All of the participants state that the expression of "I am Turkish" is suitable for them.

$\checkmark$ It is stated that $17.5 \%$ of the participants' fathers are not literate, $15.1 \%$ are primary school graduates, $13.3 \%$ are middle school graduates, $12 \%$ are high school graduates and $20.5 \%$ are college graduates and $21,7 \%$ of them have university/masters/doctoral education.

$\checkmark$ It is seen that $27.7 \%$ of the participants' mothers are not literate, $22.3 \%$ are primary school graduates, $24.7 \%$ are middle school graduates and $25.3 \%$ have high school education.

$\checkmark$ The income level of the participants' families perceived as $1.2 \%$ of middle income, $49.4 \%$ of middle income and $49.4 \%$ of income level. The income level perceived by the participants' families are lower middle income for $1,2 \%$, middle income for $49,4 \%$ and upper middle income for $49,4 \%$.

Table 2. Scale Total Score and t Test Table between Sub-Dimensions and Gender

\begin{tabular}{|c|c|c|c|c|c|c|c|}
\hline Dimensions & Gender & $\mathrm{N}$ & $\bar{X}$ & ss & $\mathrm{t}$ & $\mathrm{Sd}$ & $\mathrm{p}$ \\
\hline \multirow{2}{*}{ Personal } & Male & 106 & 28,7170 & 5,04976 & $-2,889$ & 164 & ,004 \\
\hline & Female & 60 & 30,9500 & 4,27220 & & & \\
\hline \multirow{2}{*}{ Social } & Male & 106 & 20,6698 & 3,32586 & $-2,050$ & 164 & ,042 \\
\hline & Female & 60 & 21,8667 & 4,07750 & & & \\
\hline \multirow{2}{*}{ Collective } & Male & 106 & 23,6792 & 4,43266 & $-1,178$ & 164 & ,240 \\
\hline & Female & 60 & 24,5000 & 4,08594 & & & \\
\hline \multirow{2}{*}{ Total Scale Score } & Male & 106 & 103,0377 & 8,25305 & $-3,329$ & 164 & ,001 \\
\hline & Female & 60 & 107,5167 & 8,46026 & & & \\
\hline
\end{tabular}

In Table 2, gender and scale total scores are checked by t test analysis to see whether there is a significant difference between personal, social and collective sub-dimensions. Furthermore, the homogeneity of group variances is controlled by the Test of Homogeneity of Variances test and it is seen that the groups are homogeneously distributed (SH>,05). Table 2 shows that there is a significant difference between personal and social sub-dimensions regarding gender and scale total scores and sub-dimensions $(\mathrm{p}<0,05)$. Nevertheless, there is no significant difference between gender and scale total score and collective sub-dimension score $(\mathrm{p}>0,05)$. It is possible to state that the significant difference is favorable to women as a result of studying the mean scores $(\overline{\boldsymbol{X}})$. This data shows that the genders of the participants differentiate the scale total score and the collective sub-dimension score as a factor, but not the personal and social sub-dimension scores.

Table 3. Correlation Analysis Table between Age of Individuals and Scale Total Score

\begin{tabular}{|c|c|c|c|c|c|}
\hline & $\begin{array}{l}\text { Age of the } \\
\text { Individual }\end{array}$ & Total Points & Personal & Social & Collective \\
\hline \multirow{2}{*}{ 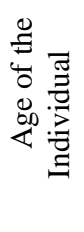 } & 1 & ,122 & ,038 & ,034 & ,093 \\
\hline & 166 & 166 & 166 & 166 & 166 \\
\hline \multirow{2}{*}{ 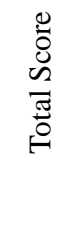 } &, 122 & 1 &, 550 & ,469 &, 563 \\
\hline & 166 & 166 & 166 & 166 & 166 \\
\hline \multirow{2}{*}{ 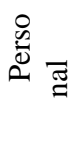 } & ,038 &, 550 & 1 &,- 011 & ,020 \\
\hline & ,626 &, 000 & & ,886 & ,803 \\
\hline
\end{tabular}




\begin{tabular}{|c|c|c|c|c|c|}
\hline & 166 & 166 & 166 & 166 & 166 \\
\hline \multirow{3}{*}{$\begin{array}{l}\bar{\pi} \\
\overline{8} \\
n^{2}\end{array}$} & ,034 & 469, & -011 & 1 & 069, \\
\hline & 661, & ,000 & 886, & & ,374 \\
\hline & 166 & 166 & 166 & 166 & 166 \\
\hline \multirow{3}{*}{$\frac{\stackrel{\partial}{0}}{\stackrel{0}{0}}$} & ,093 & ,563 & ,020 & 069, & 1 \\
\hline & ,233 & ,000 & 803 & ,374 & \\
\hline & 166 & 166 & 166 & 166 & 166 \\
\hline
\end{tabular}

$* *$ Correlation value is at 0.01 level.

The relationship between the age of the individual and the scale total score was reviewed by Pearson Correlation analysis. Relationship level interpretation in Pearson correlation (r) analysis is carried out as follows;

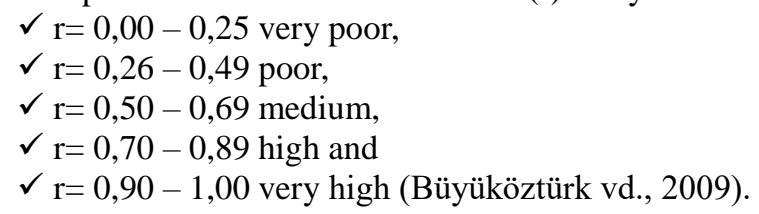

When the Table 3 is reviewed, it is seen that there is a very poor and positive $(r=, 122: p>0,05)$ relationship between the age of the individual and scale total score and sub-dimensions.

Table 4. ANOVA Test Table between Marital Status and Scale Total Score and Sub-Dimensions

\begin{tabular}{|c|lccccc|cc}
\hline \multirow{2}{*}{ Dimensions } & $\begin{array}{c}\text { Marital } \\
\text { Status }\end{array}$ & $\mathrm{N}$ & $\mathrm{KT}$ & $\mathrm{Sd}$ & KO & F & Significa \\
& Married & 49 & 2,822 & 2 & 1,411 &, 058 &, 943 \\
Personal Difference
\end{tabular}

In Table 4, ANOVA analysis is used to check whether there is a significant difference between marital status and scale total scores, personal, social and collective sub-dimensions. Furthermore, homogeneous distributions of the groups controlled by the Test of Homogeneity of Variance test, in which group variances are homogeneously distributed (SH>,05). When Table 4 is reviewed, it is found that there is no significant difference between marital status and scale total scores and sub-dimensions ( $\mathrm{p}>0,05$ ). This data can be interpreted as indicating that the marital status of the participants does not significantly change the scale total scores, personal, social and collective sub-dimension scores. 
European Journal of Science and Technology

Table 5. ANOVA Test Table between Educational Status and Scale Total Score and Sub-Dimensions

\begin{tabular}{|c|c|c|c|c|c|c|c|c|}
\hline Dimensions & Educational Status & $\mathrm{N}$ & KT & $\mathrm{Sd}$ & $\mathrm{KO}$ & $\mathrm{F}$ & $\mathrm{p}$ & $\begin{array}{r}\text { Significa } \\
\text { nt Difference }\end{array}$ \\
\hline \multirow{4}{*}{ Personal } & High School & 4 & 38,085 & 3 & 12,695 & \multirow[t]{4}{*}{, 526} & \multirow[t]{4}{*}{,665 } & \multirow[t]{4}{*}{-} \\
\hline & College & 50 & 3907,318 & 162 & 24,119 & & & \\
\hline & University & 61 & 3945,404 & 165 & & & & \\
\hline & Master/Doctorate & 51 & & & & & & \\
\hline \multirow{3}{*}{ Social } & College & 50 & 2175,815 & 162 & 13,431 & \multirow{3}{*}{, 532} & \multirow{3}{*}{661} & \multirow{3}{*}{ - } \\
\hline & University & 61 & 2197,259 & 165 & & & & \\
\hline & Master/Doctorate & 51 & & & & & & \\
\hline \multirow{2}{*}{ Collective } & High School & 4 & 91,564 & 3 & 30,521 & \multirow[t]{2}{*}{1,658} & \multirow[t]{2}{*}{, 178 } & \multirow[t]{2}{*}{-} \\
\hline & Master/Doctorate & 51 & & & & & & \\
\hline \multirow{4}{*}{$\begin{array}{l}\text { Total Scale } \\
\text { Score }\end{array}$} & High School & 4 & 384,310 & 3 & 128,10 & \multirow[t]{4}{*}{1,765} & \multirow[t]{4}{*}{, 156 } & \multirow[t]{4}{*}{-} \\
\hline & College & 50 & 11759,11 & 162 & 72,587 & & & \\
\hline & University & 61 & $\underset{\mathrm{o}}{12143,42}$ & 165 & & & & \\
\hline & Master/Doctorate & 51 & & & & & & \\
\hline
\end{tabular}

In Table 5, ANOVA analysis is used to check whether there is a significant difference between education status and scale total scores, personal, social and collective sub-dimensions. Furthermore, homogeneous distributions of the groups controlled by the Test of Homogeneity of Variance test, in which group variances are homogeneously distributed (SH>,05). When Table 5 is reviewed, it is seen that there is no significant difference between educational status and scale total scores and sub-dimensions ( $\mathrm{p}>0,05)$. Participants educational status and scale total scores and personal, social and collective sub-dimensions are similar to each other and participants in married, single or divorced groups gave similar answers.

Table 6. $\mathrm{t}$ Test Tables Between Scale Total Score and Sub-Dimensions and Educational Status in Germany

\begin{tabular}{|c|c|c|c|c|c|c|c|}
\hline Dimensions & $\begin{array}{l}\text { Educational status } \\
\text { in Germany }\end{array}$ & $\mathrm{N}$ & $\bar{X}$ & ss & $\mathrm{t}$ & $\mathrm{Sd}$ & $\mathrm{p}$ \\
\hline \multirow{2}{*}{ Personal } & Yes & 93 & 29,6774 & 5,06943 & ,455 & 164 & ,650 \\
\hline & No & 73 & 29,3288 & & & & \\
\hline \multirow{2}{*}{ Social } & Yes & 93 & 20,9892 & 3,55850 &,- 450 & 164 & ,653 \\
\hline & No & 73 & 21,2466 & 3,78146 & & & \\
\hline \multirow{2}{*}{ Collective } & Yes & 93 & 24,1290 & 4,33696 &, 515 & 164 & ,607 \\
\hline & No & 73 & 23,7808 & 4,31163 & & & \\
\hline \multirow{2}{*}{$\begin{array}{l}\text { Total Scale } \\
\text { Score }\end{array}$} & Yes & 93 & 104,7204 & 7,93912 & ,108 & 164 & ,914 \\
\hline & No & 73 & 104,5753 & 9,38663 & & & \\
\hline
\end{tabular}

In Table 6, it is checked by t test analysis whether there is a significant difference between the educational status in Germany and scale total scores, personal, social and collective sub-dimensions. Furthermore, homogeneous distributions of the groups controlled by the Test of Homogeneity of Variance test, in which group variances are homogeneously distributed (SH>,05). When Table 6 is reviewed, it is seen that there is no meaningful difference between the educational status in Germany and the scale total scores and sub-dimensions $(\mathrm{p}>0,05)$. The data can be interpreted as the total score of the identity scale and the scores of personal, social and collective sub-dimensions do not vary in the case of receiving or not receiving education in Germany and the answers are similar. 
Table 7. $\mathrm{t}$ Test Score between Scale Total Score and Sub-Dimensions and Occupational Status

\begin{tabular}{|c|c|c|c|c|c|c|c|}
\hline Dimensions & $\begin{array}{l}\text { Occupational } \\
\text { Status }\end{array}$ & $\mathrm{N}$ & $\bar{X}$ & ss & $\mathrm{t}$ & $\mathrm{Sd}$ & $\mathrm{p}$ \\
\hline \multirow{2}{*}{ Personal } & Yes & 84 & 29,5833 & 5,00652 &, 158 & 164 & ,875 \\
\hline & No & 82 & 29,4634 & 4,79762 & & & \\
\hline \multirow{2}{*}{ Social } & Yes & 84 & 21,2143 & 3,59408 & ,399 & 164 & ,691 \\
\hline & No & 82 & 20,9878 & 3,72345 & & & \\
\hline \multirow{2}{*}{ Collective } & Yes & 84 & 24,1905 & 4,54821 & ,647 & 164 & ,518 \\
\hline & No & 82 & 23,7561 & 4,08116 & & & \\
\hline \multirow{2}{*}{$\begin{array}{l}\text { Total Scale } \\
\text { Score }\end{array}$} & Yes & 84 & 105,1548 & 8,33702 & ,756 & 164 & ,451 \\
\hline & No & 82 & 104,1463 & 8,84171 & & & \\
\hline
\end{tabular}

In Table 7, it is checked by t test analysis whether there is a significant difference between occupational status and scale total scores, personal, social and collective sub-dimensions. Furthermore, homogeneous distributions of the groups controlled by the Test of Homogeneity of Variance test, in which group variances are homogeneously distributed ( $\mathrm{SH}>, 05)$. When Table 7 is examined, it is seen that there is no significant difference between occupational status and scale total scores and sub-dimensions ( $\mathrm{p}>0,05)$. Participants with and without profession can be interpreted as having answers that are similar to scale questions and their scores are similar to each other.

Table 8. $\mathrm{t}$ Test Table Between Scale Total Score and Sub-Dimensions and Having a Vocational Certificate

\begin{tabular}{|c|c|c|c|c|c|c|c|}
\hline Personal & No & 93 & 29,0108 & 4,56474 & 1,508 & 143,578 & ,134 \\
\hline Social & No & 93 & 21,4624 & 3,68770 & $-1,445$ & 156,912 &, 151 \\
\hline \multirow{2}{*}{ Collective } & Yes & 73 & 24,1370 & 4,34075 & ,425 & 164 & ,671 \\
\hline & No & 93 & 23,8495 & 4,31616 & ,425 & 154,361 & ,672 \\
\hline
\end{tabular}

In Table 8, the presence of a vocational certificate and the scale total scores are checked by test analysis to see whether there is a significant difference between personal, social and collective sub-dimensions. Furthermore, homogeneous distributions of the groups controlled by the Test of Homogeneity of Variance test, in which group variances are homogeneously distributed ( $\mathrm{SH}>, 05)$. When Table 8 is reviewed, it is seen that there is no significant difference between scale status scores and sub-dimensions when there is a vocational certificate $(\mathrm{p}>0,05)$. This data can be interpreted as the fact that whether the participants have a vocational certificate or not does not differentiate the answers to the questions on the identity scale. 
European Journal of Science and Technology

Table 9. $\mathrm{t}$ Test Score between Course/School Completion Status to Learn Profession and Scale Total Score and Sub-Dimension

\begin{tabular}{|c|c|c|c|c|c|c|c|}
\hline $\begin{array}{l}\text { Dimension } \\
\mathrm{s}\end{array}$ & $\begin{array}{l}\text { Course/School } \\
\text { Completion Status } \\
\text { to Learn Profession }\end{array}$ & $\mathrm{N}$ & $\bar{X}$ & ss & $\mathrm{t}$ & $\mathrm{Sd}$ & $\mathrm{p}$ \\
\hline \multirow{2}{*}{ Personal } & Yes & 94 & 29,6277 & 4,94917 &, 311 & 164 & ,756 \\
\hline & No & 72 & 29,3889 & 4,84275 & & & \\
\hline \multirow{2}{*}{ Social } & Yes & 94 & 21,1064 & 3,55742 & ,016 & 164 & ,987 \\
\hline & No & 72 & 21,0972 & 3,79087 & & & \\
\hline \multirow{2}{*}{ Collective } & Yes & 94 & 23,5745 & 4,02543 & $-1,373$ & 164 & , 172 \\
\hline & No & 72 & 24,5000 & 4,64515 & & & \\
\hline \multirow{2}{*}{$\begin{array}{l}\text { Total Scale } \\
\text { Score }\end{array}$} & Yes & 94 & 104,3723 & 8,71531 &,- 487 & 164 & ,627 \\
\hline & No & 72 & 105,0278 & 8,44364 & & & \\
\hline
\end{tabular}

In Table 9, it is checked by t-test analysis whether there is a significant difference between the course/school completion to learn profession status and scale total scores, personal, social and collective sub-dimensions. Furthermore, homogeneous distributions of the groups controlled by the Test of Homogeneity of Variance test, in which group variances are homogeneously distributed (SH>,05). When Table 9 is reviewed, it was found that there is no significant difference between the course/school completion status to learn profession and scale total scores and sub-dimensions $(p>0,05)$. It is possible to interpret that for the participants to complete their course/school to learn profession does not differentiate in a way to cause a significant change in the answers to the questions on the identity scale.

Table 10. $\mathrm{t}$ Test Table between Scale Total Score and Sub-Dimensions and Employment Status

\begin{tabular}{|c|c|c|c|c|c|c|c|}
\hline Dimensions & Employment Status & $\mathrm{N}$ & $\bar{X}$ & ss & $\mathrm{t}$ & $\mathrm{Sd}$ & $\mathrm{p}$ \\
\hline \multirow{2}{*}{ Personal } & Yes & 86 & 30,0465 & 4,97028 & 1,432 & 164 & ,154 \\
\hline & No & 80 & 28,9625 & 4,76921 & & & \\
\hline \multirow{2}{*}{ Social } & Yes & 86 & 20,9419 & 3,73018 &,- 587 & 164 & ,558 \\
\hline & No & 80 & 21,2750 & 3,57550 & & & \\
\hline \multirow{2}{*}{ Collective } & Yes & 86 & 24,0233 & 4,35208 &, 146 & 164 & ,884 \\
\hline & No & 80 & 23,9250 & 4,30418 & & & \\
\hline \multirow{2}{*}{$\begin{array}{l}\text { Total Scale } \\
\text { Score }\end{array}$} & Yes & 86 & 105,5233 & 8,11640 & 1,353 & 164 &, 178 \\
\hline & No & 80 & 103,7250 & 9,00770 & & & \\
\hline
\end{tabular}

In Table 10, $\mathrm{t}$ test analysis is used to check whether there is a significant difference between the employment status and scale total scores, personal, social and collective sub-dimensions. Furthermore, homogeneous distributions of the groups controlled by the Test of Homogeneity of Variance test, in which group variances are homogeneously distributed (SH>,05). When Table 10 is reviewed, it is seen that there is no significant difference between the employment status and scale total scores and sub-dimensions ( $\mathrm{p}>0,05)$. This data can be expressed as there is no significant difference between the scores regarding whether the participants work or not. 
Table 11. ANOVA Test Table between Citizenship Status and Scale Total Score and Sub-Dimensions

\begin{tabular}{|c|cccccc|c|c|}
\hline $\begin{array}{c}\text { Dimensio } \\
\text { ns }\end{array}$ & Citizenship Status & N & KT & Sd & KO & F & P & Significant \\
Difference
\end{tabular}

In Table 11, ANOVA analysis is used to check whether there is a significant difference between citizenship status and scale total scores, personal, social and collective sub-dimensions. Furthermore, homogeneous distributions of the groups controlled by the Test of Homogeneity of Variance test, in which group variances are homogeneously distributed ( $\mathrm{SH}>, 05)$. When Table 11 is reviewed, it is found that there is no significant difference between citizenship status and scale total scores and sub-dimensions ( $>>0,05)$. The fact that the participants are German, Turkish or both German and Turkish citizens does not affect the answers given to the identity scale.

Table 12. ANOVA Test Table between the Generation Living in Germany and the Scale Total Score and Sub-Dimensions

\begin{tabular}{|c|c|c|c|c|c|c|c|}
\hline Dimensions & $\begin{array}{l}\text { Generation Living } \\
\text { in Germany }\end{array}$ & $\mathrm{N}$ & $\bar{X}$ & ss & $\mathrm{t}$ & $\mathrm{Sd}$ & $\mathrm{p}$ \\
\hline \multirow{2}{*}{ Personal } & Second Generation & 79 & 30,0380 & 5,12020 & 1,293 & 164 & 198 \\
\hline & Third Generation & 87 & 29,0575 & 4,65147 & & & \\
\hline \multirow{2}{*}{ Social } & Second Generation & 79 & 21,2025 & 3,64931 & ,336 & 164 & ,737 \\
\hline & Third Generation & 87 & 21,0115 & 3,66788 & & & \\
\hline \multirow{2}{*}{ Collective } & Second Generation & 79 & 23,7848 & 4,24467 &,- 542 & 164 & ,588 \\
\hline & Third Generation & 87 & 24,1494 & 4,39749 & & & \\
\hline \multirow{2}{*}{$\begin{array}{l}\text { Total Scale } \\
\text { Score }\end{array}$} & Second Generation & 79 & 105,6076 & 9,10117 & 1,365 & 164 &, 174 \\
\hline & Third Generation & 87 & 103,7931 & 8,03066 & & & \\
\hline
\end{tabular}

In Table 10, $\mathrm{t}$ test analysis is used to check whether there is a significant difference between the generation living in Germany and scale total scores, personal, social and collective sub-dimensions. Furthermore, homogeneous distributions of the groups controlled by the Test of Homogeneity of Variance test, in which group variances are homogeneously distributed (SH>,05). When Table 10 is reviewed, it is seen that there is no significant difference between the generation living in Germany and total scale scores and subdimensions $(p>0,05)$. The scores the participants receive from the answers to the scale questions regarding which generation they are in Germany do not significantly differentiate. 
European Journal of Science and Technology

Table 13. ANOVA Test Table Between Knowledge of German and Scale Total Score and Sub-Dimensions

\begin{tabular}{|c|c|c|c|c|c|c|c|c|}
\hline $\begin{array}{l}\text { Dimensio } \\
\text { ns }\end{array}$ & $\begin{array}{l}\text { Knowledge of } \\
\text { German }\end{array}$ & $\mathrm{N}$ & KT & $\mathrm{Sd}$ & $\mathrm{KO}$ & $\mathrm{F}$ & $\mathrm{p}$ & $\begin{array}{l}\text { Significant } \\
\text { Difference }\end{array}$ \\
\hline \multirow{3}{*}{ Personal } & Very Good & 51 & 50,261 & 2 & 25,130 & \multirow[t]{3}{*}{1,052} & \multirow[t]{3}{*}{, 352} & \multirow[t]{3}{*}{ - } \\
\hline & Good & 52 & 3895,143 & 163 & 23,897 & & & \\
\hline & Intermediate & 63 & 3945,404 & 165 & & & & \\
\hline \multirow{3}{*}{ Social } & Very Good & 51 & 10,333 & 2 & 5,167 & \multirow[t]{3}{*}{, 385} & \multirow[t]{3}{*}{ 681 } & \multirow[t]{3}{*}{ - } \\
\hline & Good & 52 & 2186,926 & 163 & 13,417 & & & \\
\hline & Intermediate & 63 & 2197,259 & 165 & & & & \\
\hline \multirow{3}{*}{ Collective } & Very Good & 51 & 19,964 & 2 & 9,982 & \multirow[t]{3}{*}{, 533} & \multirow[t]{3}{*}{,588 } & \multirow[t]{3}{*}{ - } \\
\hline & Good & 52 & 3053,940 & 163 & 18,736 & & & \\
\hline & Intermediate & 63 & 3073,904 & 165 & & & & \\
\hline \multirow{3}{*}{$\begin{array}{l}\text { Total } \\
\text { Scale }\end{array}$} & Very Good & 51 & 29,114 & 2 & 14,557 & \multirow[t]{3}{*}{,196 } & \multirow[t]{3}{*}{,822 } & \multirow[t]{3}{*}{ - } \\
\hline & Good & 52 & 12114,314 & 163 & 74,321 & & & \\
\hline & Intermediate & 63 & 12143,428 & 165 & & & & \\
\hline
\end{tabular}

In Table 13, ANOVA analysis is used to check whether there is a significant difference between knowledge of German and scale total scores, personal, social and collective sub-dimensions. Furthermore, homogeneous distributions of the groups controlled by the Test of Homogeneity of Variance test, in which group variances are homogeneously distributed (SH>,05). When Table 13 is revie wed, it is seen that there is no significant difference between knowledge of German and scale total scores and sub-dimensions ( $\mathrm{p}>0,05$ ). It can be expressed that the participants' knowledge of German and the answers to the scale do not differentiate.

Table 14. ANOVA Test Table between Knowledge of Turkish and Scale Total Score and Sub-Dimensions

\begin{tabular}{|c|c|c|c|c|c|c|c|c|}
\hline Dimensions & $\begin{array}{l}\text { Knowledge of } \\
\text { Turkish }\end{array}$ & $\mathrm{N}$ & KT & $\mathrm{Sd}$ & $\mathrm{KO}$ & $\mathrm{F}$ & $\mathrm{p}$ & $\begin{array}{l}\text { Significa } \\
\text { nt Difference }\end{array}$ \\
\hline \multirow{3}{*}{ Personal } & Very Good & 66 & ,042 & 2 &, 021 & ,001 & ,999 & - \\
\hline & Good & 53 & 3945,362 & 163 & 24,205 & & & \\
\hline & Intermediate & 47 & 3945,404 & 165 & & & & \\
\hline \multirow{3}{*}{ Social } & Very Good & 66 & 2,832 & 2 & 1,416 & ,105 & ,900 & - \\
\hline & Good & 53 & 2194,427 & 163 & 13,463 & & & \\
\hline & Intermediate & 47 & 2197,259 & 165 & & & & \\
\hline \multirow{3}{*}{ Collective } & Very Good & 66 & 103,595 & 2 & 51,798 & 2,842 & ,061 & - \\
\hline & Good & 53 & 2970,309 & 163 & 18,223 & & & \\
\hline & Intermediate & 47 & 3073,904 & 165 & & & & \\
\hline \multirow{3}{*}{ Total Scale } & Very Good & 66 & 86,299 & 2 & 43,150 &, 583 &, 559 & - \\
\hline & Good & 53 & 12057,129 & 163 & 73,970 & & & \\
\hline & Intermediate & 47 & 12143,428 & 165 & & & & \\
\hline
\end{tabular}

In Table 14, ANOVA analysis is used to check whether there is a significant difference between knowledge of Turkish and scale total scores, personal, social and collective sub-dimensions. Furthermore, homogeneous distributions of the groups controlled by the Test of Homogeneity of Variance test, in which group variances are homogeneously distributed (SH>, 05). When Table 14 is reviewed, it is seen that there is no significant difference between knowledge of Turkish and scale total scores and sub-dimensions. It can be expressed that the participants' knowledge of Turkish and the answers to the scale do not differentiate.

Table 15. ANOVA Test Table between the Frequency of Visiting Turkey and Scale Total Score and Sub-Dimensions

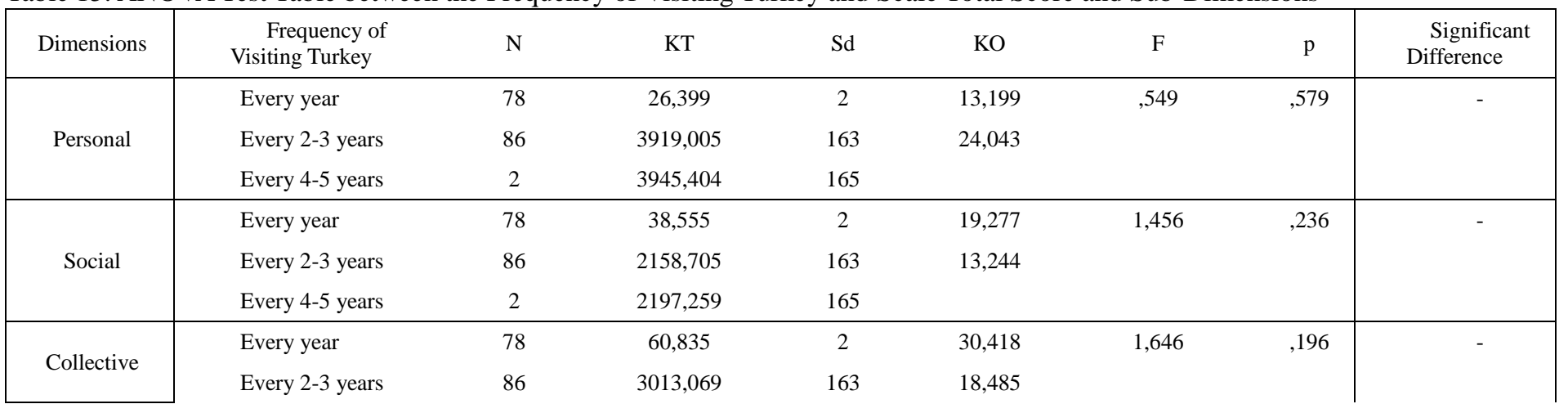




\begin{tabular}{|c|lccccc|c|}
\hline & Every 4-5 years & 2 & 3073,904 & 165 & & & \\
\hline \multirow{3}{*}{ Total Scale } & Every year & 78 & 173,049 & 2 & 86,524 & 1,178 & \\
& Every 2-3 years & 86 & 11970,379 & 163 & 73,438 & & \\
& Every 4-5 years & 2 & 12143,428 & 165 & & & \\
& & & & & & \\
\end{tabular}

In Table 15, ANOVA analysis is used to check whether there is a significant difference between frequency of visiting Turkey and scale total scores, personal, social and collective sub-dimensions. Furthermore, homogeneous distributions of the groups controlled by the Test of Homogeneity of Variance test, in which group variances are homogeneously distributed (SH>, 05). When Table 15 is reviewed, it is seen that there is no significant difference between frequency of visiting Turkey and scale total scores and subdimensions. It can be expressed that the participants' frequency of visiting Turkey and the answers to the scale do not differentiate.

Table 16. ANOVA Test Table between the Father's Educational Status and Scale Total Score and Sub-Dimensions

\begin{tabular}{|c|c|c|c|c|c|c|c|c|}
\hline Dimensions & $\begin{array}{c}\text { Father's } \\
\text { Educational Status }\end{array}$ & $\mathrm{N}$ & KT & $\mathrm{Sd}$ & KO & F & $\mathrm{p}$ & $\begin{array}{l}\text { Significant } \\
\text { Difference }\end{array}$ \\
\hline \multirow{6}{*}{ Personal } & Illiterate & 29 & 89,648 & 5 & 17,930 & \multirow[t]{6}{*}{, 744} & \multirow[t]{6}{*}{, 592} & \multirow[t]{6}{*}{ - } \\
\hline & Primary School & 25 & 3855,756 & 160 & 24,098 & & & \\
\hline & Middle School & 22 & 3945,404 & 165 & & & & \\
\hline & High School & 20 & & & & & & \\
\hline & College & 34 & & & & & & \\
\hline & $\begin{array}{c}\text { University/ } \\
\text { College/Doctorate }\end{array}$ & 36 & & & & & & \\
\hline \multirow{6}{*}{ Social } & Illiterate & 29 & 145,647 & 5 & 29,129 & \multirow[t]{6}{*}{2,272} & \multirow[t]{6}{*}{,050 } & \multirow[t]{6}{*}{-} \\
\hline & Primary School & 25 & 2051,612 & 160 & 12,823 & & & \\
\hline & Middle School & 22 & 2197,259 & 165 & & & & \\
\hline & High School & 20 & & & & & & \\
\hline & College & 34 & & & & & & \\
\hline & $\begin{array}{c}\text { University/ } \\
\text { College/Doctorate }\end{array}$ & 36 & & & & & & \\
\hline \multirow{6}{*}{ Collective } & Illiterate & 29 & 36,497 & 5 & 7,299 & \multirow[t]{6}{*}{, 385} & \multirow[t]{6}{*}{, 859} & \multirow[t]{6}{*}{-} \\
\hline & Primary School & 25 & 3037,407 & 160 & 18,984 & & & \\
\hline & Middle School & 22 & 3073,904 & 165 & & & & \\
\hline & High School & 20 & & & & & & \\
\hline & College & 34 & & & & & & \\
\hline & $\begin{array}{c}\text { University/ } \\
\text { College/Doctorate }\end{array}$ & 36 & & & & & & \\
\hline \multirow{6}{*}{ Total Scale Score } & Illiterate & 29 & 670,828 & 5 & 134,166 & \multirow[t]{6}{*}{1,871} & \multirow[t]{6}{*}{, 102} & \multirow[t]{6}{*}{-} \\
\hline & Primary School & 25 & 11472,600 & 160 & 71,704 & & & \\
\hline & Middle School & 22 & 12143,428 & 165 & & & & \\
\hline & High School & 20 & & & & & & \\
\hline & College & 34 & & & & & & \\
\hline & $\begin{array}{c}\text { University/ } \\
\text { College/Doctorate }\end{array}$ & 36 & & & & & & \\
\hline
\end{tabular}

In Table 16, ANOVA analysis is used to check whether there is a significant difference between father's educational status and scale total scores, personal, social and collective sub-dimensions. Furthermore, homogeneous distributions of the groups controlled by the Test of Homogeneity of Variance test, in which group variances are homogeneously distributed (SH>, 05). When Table 16 is reviewed, it is seen that there is no significant difference between father's educational status and scale total scores and subdimensions. It can be expressed that the participants' father's educational status and the answers to the scale do not differentiate.

Table 17. ANOVA Test Table between the Mother's Educational Status and Scale Total Score and Sub-Dimensions

\begin{tabular}{|c|c|c|c|c|c|c|c|c|}
\hline Dimensions & $\begin{array}{c}\text { Mother's } \\
\text { Educational Status }\end{array}$ & $\mathrm{N}$ & KT & $\mathrm{Sd}$ & $\mathrm{KO}$ & $\mathrm{F}$ & $\mathrm{p}$ & $\begin{array}{l}\text { Significant } \\
\text { Difference }\end{array}$ \\
\hline \multirow{4}{*}{ Personal } & Illiterate & 46 & 76,143 & 3 & 25,381 & \multirow[t]{4}{*}{1,063} & \multirow[t]{4}{*}{, 367} & \multirow[t]{4}{*}{-} \\
\hline & Primary School & 37 & 3869,261 & 162 & 23,884 & & & \\
\hline & Middle School & 41 & 3945,404 & 165 & & & & \\
\hline & High School & 42 & & & & & & \\
\hline \multirow{3}{*}{ Social } & Illiterate & 46 & 44,303 & 3 & 14,768 & \multirow[t]{3}{*}{1,111} & \multirow[t]{3}{*}{, 346} & \multirow[t]{3}{*}{-} \\
\hline & Primary School & 37 & 2152,956 & 162 & 13,290 & & & \\
\hline & Middle School & 41 & 2197,259 & 165 & & & & \\
\hline
\end{tabular}




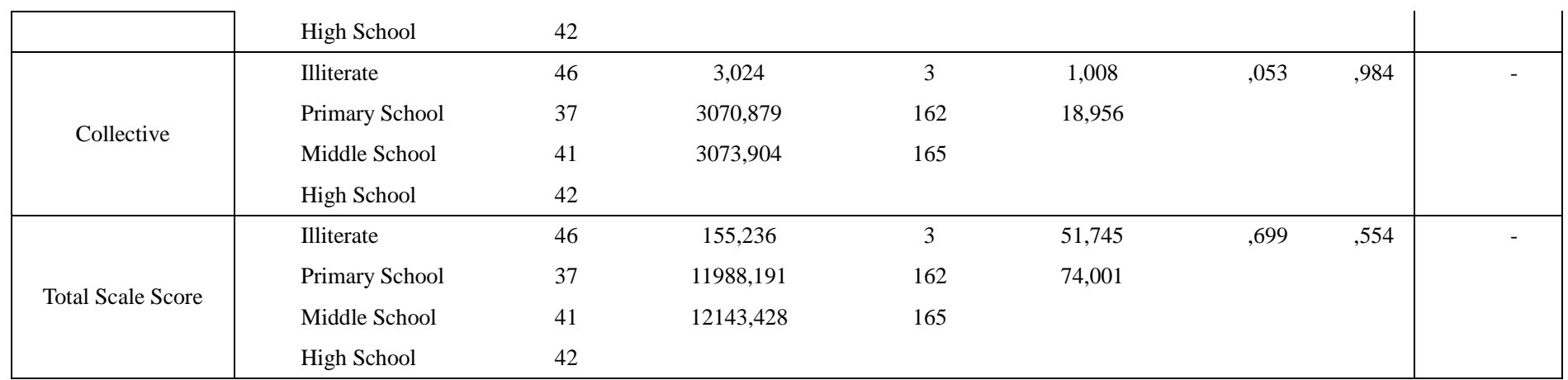

In Table 17, ANOVA analysis is used to check whether there is a significant difference between mother's educational status and scale total scores, personal, social and collective sub-dimensions. Furthermore, homogeneous distributions of the groups controlled by the Test of Homogeneity of Variance test, in which group variances are homogeneously distributed (SH>, 05). When Table 17 is reviewed, it is seen that there is no significant difference between mother's educational status and scale total scores and subdimensions. It can be expressed that the participants' mother's educational status and the answers to the scale do not differentiate.

Table 18. ANOVA Test Table between the Income Level Perceived and Scale Total Score and Sub-Dimensions

\begin{tabular}{|c|c|c|c|c|c|c|c|c|}
\hline Dimensions & Income Level & $\mathrm{N}$ & $\mathrm{KT}$ & $\mathrm{Sd}$ & $\mathrm{KO}$ & $\mathrm{F}$ & $\mathrm{p}$ & $\begin{array}{l}\text { Significant } \\
\text { Difference }\end{array}$ \\
\hline \multirow{3}{*}{ Personal } & Lower Middle Income & 2 & 34,757 & 2 & 17,379 & \multirow[t]{3}{*}{,724 } & \multirow[t]{3}{*}{,486 } & \multirow[t]{3}{*}{-} \\
\hline & Middle & 82 & 3910,646 & 163 & 23,992 & & & \\
\hline & Upper Middle & 82 & 3945,404 & 165 & & & & \\
\hline \multirow[b]{2}{*}{ Social } & Lower Middle Income & 2 & 7,491 & 2 & 3,745 & \multirow[t]{2}{*}{,279 } & \multirow[t]{2}{*}{,757 } & \multirow[t]{2}{*}{-} \\
\hline & Middle & 82 & 2189,768 & 163 & 13,434 & & & \\
\hline \multirow{3}{*}{ Collective } & Lower Middle Income & 2 & 16,318 & 2 & 8,159 & \multirow[t]{3}{*}{,435 } & \multirow[t]{3}{*}{,648 } & \multirow[t]{3}{*}{-} \\
\hline & Middle & 82 & 3057,585 & 163 & 18,758 & & & \\
\hline & Upper Middle & 82 & 3073,904 & 165 & & & & \\
\hline Total Scale & Lower Middle Income & 2 & 112,391 & 2 & 56,196 &, 761 &, 469 & - \\
\hline
\end{tabular}

In Table 18, ANOVA analysis is used to check whether there is a significant difference between the income level perceived Turkey and scale total scores, personal, social and collective sub-dimensions. Furthermore, homogeneous distributions of the groups controlled by the Test of Homogeneity of Variance test, in which group variances are homogeneously distributed (SH>, 05). When Table 18 is reviewed, it is seen that there is no significant difference between income level perceived and scale total scores and subdimensions. It can be expressed that the participants' income level perceived and the answers to the scale do not differentiate.

Table 19. Analysis of Answers to Identity Scale Questions

\begin{tabular}{|c|c|c|c|}
\hline S.N. & Questions & Average & Level of Participation \\
\hline 1 & Things you have, my stuff & 3,0783 & Very Important \\
\hline 2 & My values and moral standards (criteria) & 3,0723 & Very Important \\
\hline 4 & Becoming a member of family generations (family tree) & 2,9518 & Generally Important \\
\hline 5 & My dreams and aspirations & 2,8373 & Generally Important \\
\hline 6 & Behavioral patterns that the others have shown to the things I say and do & 3,1084 & Very Important \\
\hline 10 & My religion & 3,0060 & Very Important \\
\hline
\end{tabular}




\begin{tabular}{|c|c|c|c|}
\hline 11 & My excitements and emotions & 2,8434 & Generally Important \\
\hline 12 & What others think about me, my reputation & 2,9940 & Generally Important \\
\hline 13 & Places I live or grow & 2,9096 & Generally Important \\
\hline 14 & My thoughts and opinions & 3,0663 & Very Important \\
\hline 15 & My attraction according to others & 2,9819 & Generally Important \\
\hline 16 & Formation regarding to my age group or generation & 2,9518 & Generally Important \\
\hline 17 & My ways of coping with fear and worry & 3,0000 & Very Important \\
\hline 18 & My gender as a male or female & 2,9157 & Generally Important \\
\hline 19 & The feeling that I am a unique person as someone different from others & 2,9337 & Generally Important \\
\hline 20 & I belong to lower, middle or upper economic class & 3,1566 & Very Important \\
\hline 21 & $\begin{array}{l}\text { The fact that I will continue to stay the same even though life causes many } \\
\text { changes in my appearances }\end{array}$ & 3,0542 & Very Important \\
\hline 22 & Impression and style I made on others with my gestures and movements & 3,0663 & Very Important \\
\hline 23 & My sense of belonging to society & 2,9880 & Generally Important \\
\hline 24 & Self-knowledge, my thoughts on what kind of person I really am & 3,0000 & Very Important \\
\hline 25 & $\begin{array}{l}\text { When I get together with other people, my social behavior as the behavior I } \\
\text { display }\end{array}$ & 2,9639 & Generally Important \\
\hline 26 & To be proud of my country, to feel proud as a citizen & 3,2711 & Very Important \\
\hline 27 & My physical abilities/skills, which are good and coordinated in activities & 2,9036 & Generally Important \\
\hline 28 & Personal self-worth, personal opinion about myself & 2,9759 & Generally Important \\
\hline 29 & Formation of a sports fanatic identified with a sports team & 2,9217 & Generally Important \\
\hline 30 & My professional preferences and career plans & 3,0000 & Very Important \\
\hline 31 & My interest in political issues & 2,8916 & Generally Important \\
\hline 32 & $\begin{array}{l}\text { My academic talents and performances, such as the advice and the grades I } \\
\text { earned from my teachers }\end{array}$ & 3,0542 & Very Important \\
\hline 33 & Knowledge of regional accent, pronunciation or second language & 3,0482 & Very Important \\
\hline 34 & My role in the university as a student & 3,0120 & Very Important \\
\hline 35 & My sexual orientation as heterosexual or homosexual & 3,0602 & Very Important \\
\hline
\end{tabular}

The answers that individuals gave to the questionnaire on identity scale are analyzed in Table 19 and the levels of participation are determined. When Table 19 is reviewed, it is seen that the average scores of the participants in the overall questionnaire survey are generally important (between 2 and 3) or very important (between 3 and 4).

\section{Conclusion}

When reviewed in general, there is no significant difference ( $p>0.05)$ in scale total scores, personal, social and collective subdimensions except participants' gender. There is a significant difference $(\mathrm{p}<0.05)$ between the gender variable and the scale total score and the collective sub-dimension. Nevertheless, when the question "What are the problems of citizens of Turkish origin living in Germany?" is asked, the answers related exclusion, discrimination and cultural differences are collected. When the most suitable nationality is asked to the participants, all participants answered as "I am Turkish." It is seen that the participants with German citizenship, Turkish citizenship and Turkish and German citizenship are involved. Therefore, it is possible to suggest that the participants' citizenship status has not changed their answer regarding the most suitable nationality. 


\section{References}

Akkaş, H. : (2009 /2010) Mediale Integration türkischer Migranten in Deutschland. Masterarbeit. Universiteat Siegen

Büyüköztürk, Ş., Çakmak, E. K., Akgün, Ö. E., Karadeniz, Ş., \& Demirel, F. (2009). Bilimsel araştırma yöntemleri. Ankara: Pegem A Yayınları.

Coşkun, H. (2004). Kimlik Ölçeğinin bir Türk örnekleminde geçerlik ve güvenirlik çalışması. Türk Psikoloji Yazıları Dergisi, 7(14), 49-60.

Cheek, J. M., \& Tropp, L. R. (1995). The aspects of Identity Questionnaire: History and Bibliography (2nd ed.). Wellesley College, MA.

Daresh, H.B. (1984) The Authoritarian Family and Its Adolescents. Canadian Physchiatry Association Journal. Vol: 23,87. Ottowa

Kulaksizoğlu, A. (2002/2003) Probleme der türkischen Jugendlichen der dritten Generation in Deutschland. Der Zusammenhang zwischen dem Erziehungsverhalten der Eltern und den Problemen der Jugendlichen. Essen /Deutschland

Karasar, N. (2015). Bilimsel Araştırma Yöntemi (28. Bask1). Ankara: Nobel Yayınları.

Schu, C. (2017). Sachverstandigenrat deutscher Stiftunggen für İntegration und Migranten, Fakten zur Einwanderung in Deutschland. Hrsg, Sachvertandigenrat deutscher Stiftungen für İntegration und Migranten (SVR) GmbH.

Öztunç, H., Bilge, Y., Bilge, Y. (2015) Kişilk Bozuklukları ile Gelir ve Cinsiyet Değişkenlerinin İlişkinin İncelenmesi. Sosyal Bilimleri Dergisi /Journal of Social Sciences. Cilt / Volume VIII.Sayı / Number 1

Goldenberg, A. (2000). Kuzey Ren Vestfalya Eyaletlerinde Türk Gençliği. Türkiye ve Avrupa'da Gençlik TDV-Türk Demokrasi Vakfi, Adenauer Vakfi Ankara.

Sprinthall, N.H., Collins., (1984). W.A. Adolescent Psychology, New York: Rondom House.

Impressium interIkultur ( 2011). İnterkultur erscheint als regelmassige Beilage zur Zeitung politik und kultur, herausgegeben von Olaf Zmimmermann und Theo Geissler. ISSN 1867-5557 